\title{
Community engagement in Australian local governments: A closer look and strategic implications
}

\author{
Public input into decision-making through participatory and deliberative \\ democratic practices has become a widely accepted and legislated responsibility \\ of Australian local governments. At any one time, councils are leading \\ submission processes, workshops and online surveys on a multitude of projects, \\ ranging from long-term community strategic plans to public art projects. The \\ increase in these practices has been exponential, leaving little time for critical \\ reflection. The lack of empirical data to illustrate how community engagement is \\ understood and practised in different councils has hindered sector-wide \\ reflection. This paper presents the findings of the 'Local Government \\ Community Engagement Census', a survey of 175 councils - approximately half \\ - from four of Australia's eastern states. This sectoral snapshot provides a picture \\ of how councils understand, prioritise and practise community engagement, \\ allowing critical reflection, an interpretation of implications and suggesting areas \\ for future research.
}

Keywords: Community engagement; local government; public administration; public participation

\section{Introduction}

Australians citizens can vote in local elections held in the local government jurisdictions of the six states and the Northern Territory, thereby receiving local democratic representation. However, communities increasingly have the opportunity to be involved in local decision-making through participatory democratic processes, widely known in Australia as community engagement. Community engagement can be defined as a process 'by which the aspirations, concerns, needs and values of citizens and communities are incorporated at all levels and in all sectors in policy development, planning, decision-making, service delivery and assessment; and by which governments and other business and civil society organisations involve citizens, clients, communities 
and other stakeholders in these processes' (United Nations 2005). Without exception, the Local Government Acts of Australia's jurisdictions list engagement as a normative principle; further stipulating that councils must engage their communities (Local Government Act 1989 (Vic); Local Government Act 1993 (NSW); Local Government Act 1993 (Tas); Local Government Act 1995 (WA); Local Government Act 1999 (SA); Local Government Act 2009 (Qld); Local Government Act 2017 (NT)). Consequently, many - but, as we shall see, by no means all - Australian local governments have community engagement policies, plans, staff positions and resources dedicated to this function. However, precisely how community engagement has permeated local government remains the subject of inquiry, due at least partly to a lack of empirical research (Fung 2015). The research presented in this paper seeks to redress these gaps by presenting findings of a census into local government community engagement practices.

Despite the ambiguities surrounding its meaning/s, community engagement is now a widely-accepted function of Australian local government. While some see this as a 'paradigm shift' in the way democracy is practised (Aulich 2009; Stoker 2006), others remain sceptical (Head 2007). Regardless, the proliferation of practice would suggest that councils are seeing the benefits beyond merely meeting legislative requirements. Much of the literature about community engagement practices in Australian local governments - indeed more generally -focuses on the theoretical dimensions and normative efficacy of these practices (Christensen and Grant 2016; Hendriks \& Carson 2008; Hendriks et al. 2013); the role of participation in governance (Aulich 2009; Gollagher and Hartz-Karp 2013; Reddel and Woolcock 2004), the various types and levels of participation (Bishop and Davis 2002; Head 2007), the legislative and contextual development (Grant and Drew 2017; Grant et al. 2011), its benefits and 
impacts (Head 2007; Reddel and Woolcock 2004), its role in public policy (Adams and Hess 2001; Bishop and Davis 2002; Head 2011) and examinations of specific methods (Carson and Hartz-Karp 2005; Hartz-Karp 2012; Hendriks et al. 2013).

While this research contributes to understandings of community engagement in Australian local government it does not facilitate a strategic understanding of how most local governments are practically interpreting this rapidly developing element of their own operations. The 'sectoral' view that is provided by the research presented here allows scholars to identify which community engagement practices are being adopted and adapted by which types of councils, allowing for comparison and critical reflections. For public administrators, practitioners and policy makers, this research provides a benchmark which can assist in evaluation and policy change.

This paper presents the findings of a census of local government community engagement practice. Globally, similar studies include a survey of 310 of 332 authorities in the United Kingdom (Lowndes et al. 2001) and a survey of 249 of 541 cities with populations larger than 50,000 in the United States (Wang 2001). Not only does the Australian context and setting vary, but developments in community engagement practice have moved at a rapid pace. Consequently, this study presents a snapshot of Australian practice.

The paper is divided into five main sections. We start with a brief contextualisation of community engagement followed by an overview of Australian local government. We then present an explanation of the objectives and methodology. We then present the findings in order of the questions in the census, namely: the amount of engagement conducted by councils; the methods they are using; the drivers for engaging; responsibility for planning and delivering the engagement; and the challenges 
in planning and delivering engagement. The paper concludes by suggesting areas of future analysis and research required to provide a fuller picture of current practice.

\section{Community Engagement}

While this is primarily an empirical study, a short discussion of how community engagement is defined and theorised is useful. The term 'community engagement' (also known as public participation) has become near-ubiquitous; yet its precise definition remains contested. The United Nations (2005) definition cited in our introduction speaks of the incorporation of aspirations and needs into policy, planning and service delivery at multiple levels of government. Rowe and Frewer (2005) and the international industry body International Association for Participation 2 (IAP2) (2018) follow suit, with definitions involving the community in decision-making. Cavaye $(2004,3)$ refers to it as is 'mutual communication and deliberation that occurs between government and citizens'. While the intent underlying these definitions is noble, the exact meaning is unclear. Attempts to clarity the term include explorations of the levels of involvement available to communities (see Arnstein 1969; Dean 2016; Fung 2006; IAP2 2014). Also included are examinations of the different purposes of community engagement (see for example Bryson et al. 2013), whether they are policy related (Bua and Escobar 2008; Head 2007; Michels and De Graaf 2017) or part of large strategies such as collaborative governance (Ansell and Gash 2008; Fung and Wright 2003).

Notwithstanding the ambiguity of the term, three broad approaches to community engagement can be discerned. First, community engagement is discussed as an a priori theoretical concept, positioned within discussions of democracy generally and local democracy specifically - where it is placed at the core of participatory practices that are (in turn) juxtaposed against representative democratic procedures, 
particularly voting (see Christensen and Grant 2016; Haus and Sweeting 2006; Pratchett 2004). Second, an institutional approach can also be identified. This places to one side explicit theorisation and focuses instead upon the legislative and regulatory definitions of the term, usually emphasising reform processes and the ramifications of these for intergovernmental relations - an approach that is popular in Australia (Aulich 2009; Grant and Drew 2017; Grant et al. 2011). Third, understandings of community engagement that are drawn from reflecting on the embedded practice of local governments and other actors, where the meaning is contextualised (Hendriks and Carson 2008; Lowndes et al. 2001) and which place community engagement in broader political and policy frameworks (Ansell and Gash 2008; Fung and Wright 2003; Head 2007). It is these three broad approaches that inform the methodological strategy of our research. This empirical study is situated within what we have identified as the embedded practice element of research on community engagement. Nevertheless, it also informs the theoretical and institutional approaches. All three approaches are revisited in the penultimate section of our discussion.

\section{Australian Local Government}

The Australian Constitution enacted in 1901 presents a system of government comprised of federal and state levels, yet local government as an element of the individual colonial governments has existed since the 1840s (see Power et al. 1981). Whether Australian local governments emerged as response to local demand or whether it was the result of the legislation from the colonial governments prior to federation is an issue of contention (Grant and Drew 2017). Regardless, contemporaneously the six states and the Northern Territory are responsible for legislating the powers of the local governments in their jurisdictions. Consequently, while there are some overarching 
similarities in the roles and responsibilities of local governments across the federation, there are differences.

There are currently 546 local governments in the Australian federation as shown in Figure 1.

Figure $1 \quad$ Australia: Jurisdictions and number of local governments

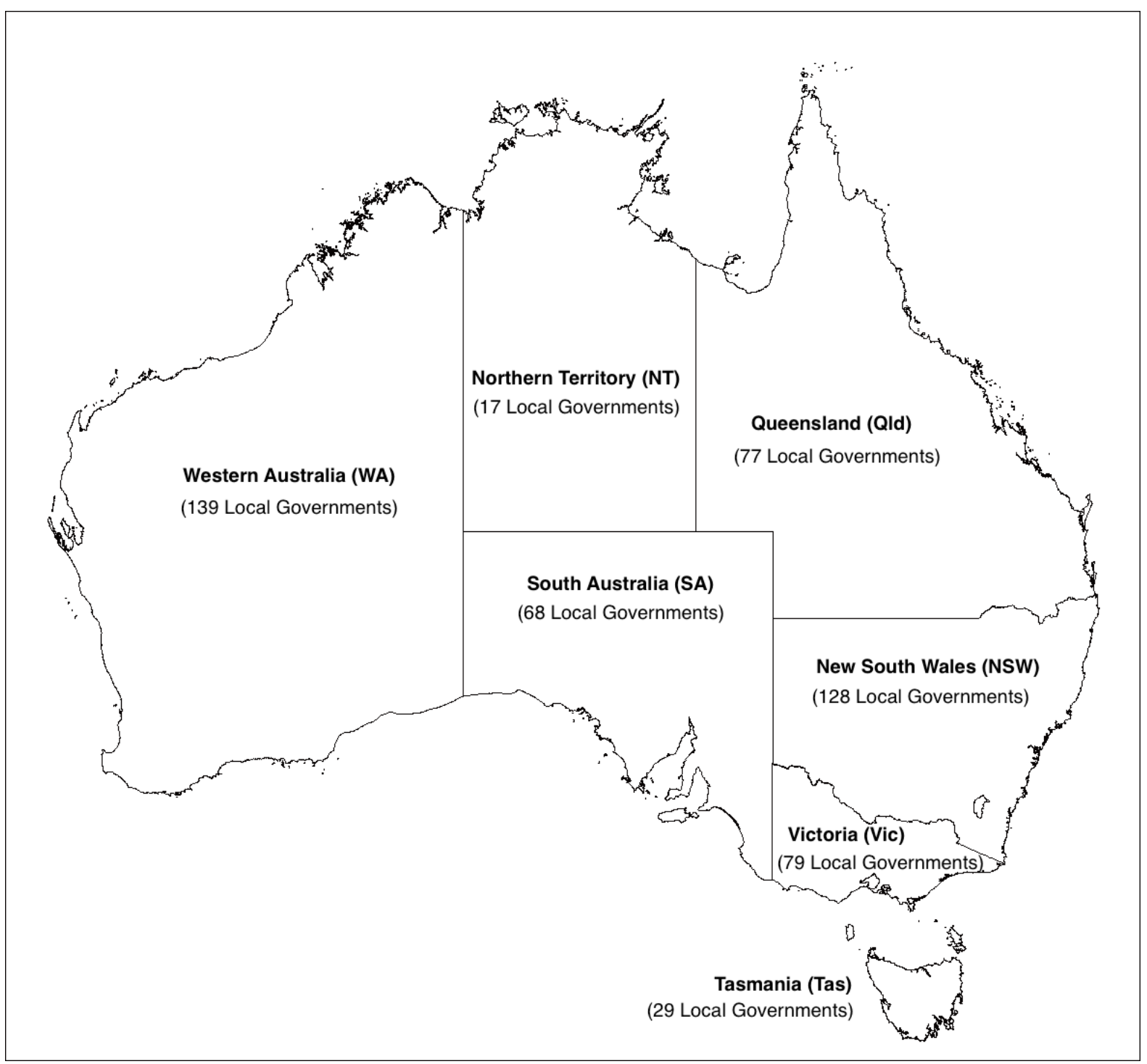

Source: Adapted from Grant and Drew (2017:360) and Office of Local Government NSW (2018) 
The councils vary considerably in geographic and population sizes and the Department of Infrastructure and Regional Development's (DIRD 2017) Australian Classification of Local Governments (ACLG) system is used as the reference by the federal government when allocating financial grants (indeed more broadly). The ACLG identifies 21 types, ranging from Urban Capital Cities (UCC) through to Remote Extra Small (RTX) although DIRD (2017) warns there is still considerable divergence within these types. A summary is presented in the Appendix. For this study, the council types have been grouped using the ACLG with adjustments made to reflect changes since the system was last updated. ${ }^{1}$ The groups used in this study are: Capitals and Metro, Urban Regional, Urban Fringe, and Rural and Remote.

\section{Objectives and methodology}

The research questions for this project were: What are the community engagement practices of Australian local governments? How is community engagement positioned inside Australian local governments? What is driving and inhibiting practice?

After obtaining ethics approval, we emailed the 'Local Government Community Engagement Census' to all 352 local governments in New South Wales (NSW) (128), Queensland (77), South Australia (68) and Victoria (79) in April 2017. We also sent two reminder emails and used social media channels to promote participation in the census. The census contained 14 questions including: council name (for classification

\footnotetext{
${ }^{1}$ Adjustments to the ACLG are as follows: 1. Only local governments under the jurisdiction of the states' Local Government Acts have been included. This criterion excludes seven local governments in South Australia and three in New South Wales. 2. Since the publishing of the Local Government National Report 2014-2015 (DIRD 2017), NSW has undertaken a merger program and consequently the number of councils has decreased from 155 to 132 . The table has been amended to incorporate these changes using the ALGC classification system provided by DIRD (2017:218). 3. Five councils in Queensland - Gold Coast City Council, Ipswich City Council, Logan City Council, Moreton Bay Regional Council and Redland City Council - have been reclassified from Urban Regional to Urban Development. This is to more accurately reflect their status as metropolitan areas rather than regional towns. These local government areas are part of the metropolitan rail network as is typically the case with other Urban Development classifications.
} 
purposes only); the number of community engagement processes conducted in the last 12 months; the position of the community engagement function in the organisation; where responsibility for planning and delivering community engagement was located in the organisation; the number of dedicated community engagement staff; the proportion of community engagement processes designed and delivered by staff in the organisation; reasons for using external consultants, if applicable; methods used in the past, present and being considered for the future; factors driving community engagement practice; and difficulties experienced in delivering engagement from an organisational perspective. The census deliberately did not provide a definition of 'community engagement' or 'community engagement process' instead preferring respondents to apply their own understanding so that a contextualised meaning could be developed from all responses.

The responses were summarised using a descriptive analysis, with the average values by council category and/or a response category provided. A statistical analysis, incorporating hypothesis testing, was then conducted to determine if any differences could be considered statistically significant. The choice of methodology employed for each census question was determined by the type of data collected. For questions with numerical responses, Analysis of Variance (ANOVA)² was deployed. For questions with categorical responses, the Fisher exact test ${ }^{3}$ was deployed. If significant differences were found, the Tukey-Kramer Procedure (for numerical data) and Fisher exact test (for categorical data $)^{4}$ were then used to identify which individual council categories

\footnotetext{
${ }^{2}$ As the data are normally distributed parametric methods can be applied; however, verification with nonparametric methods has also be conducted to improve the robustness of results obtained.

${ }^{3}$ Note: the chi-squared test cannot be used in this instance as the expected frequencies assumption is violated.

4 The Holm-Bonferroni Sequential Correction has been used in both cases to correct for familywise error rates.
} 
differed. As with all surveys, this study suffered from weaknesses such as non-response, multiple response, reporting bias and point-in-time data.

Given the survey was administered online, the overall response rate of $49.7 \%$ (175 of 352 local governments) was relatively high. However, some types of councils had much lower response rates, for example, only $21.7 \%$ for rural and remote Queensland local governments (Figure 2). The findings of Morris (2012), who discusses engagement practices and challenges in rural remote indigenous local councils, partly fill this gap. Figure 2 shows a summary of the response rates by state and council type. The response rate from each state was above $40 \%$, with the highest rate from Victorian councils $(63.3 \%)$. Numbers of responses per council type across all states were also strong: capital and metropolitan councils (56.3\%), urban regional councils (63.4\%), urban fringe (48.3\%) and rural and remote councils (39.8\%). As discussed earlier, the responsibilities and sizes of Australian local governments vary widely which partially explains why the lowest response rate is from rural and remote Queensland - which includes 30 councils with populations less than 3,000.

\section{Figure 2 Response Rate \% by State and Council Type $(p o p=352, n=175)$}

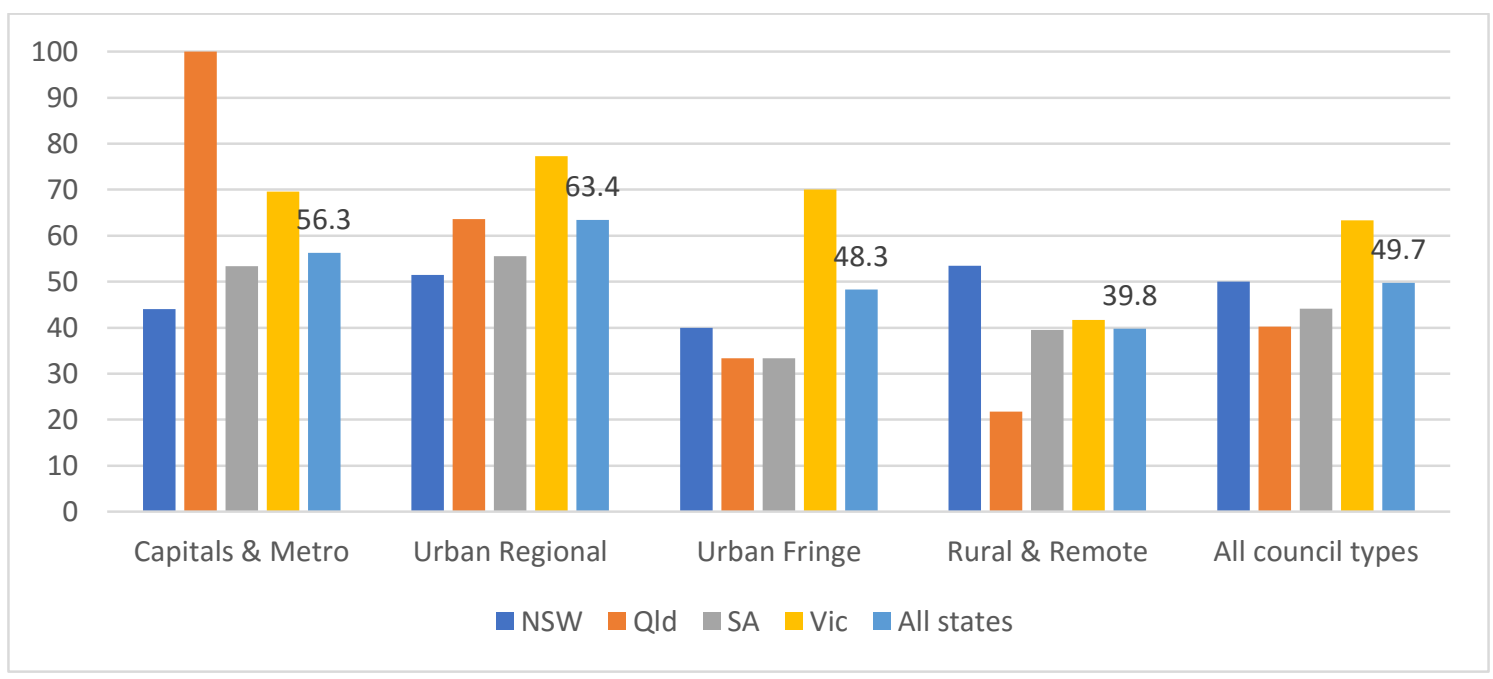


In the seven councils where more than one response was received, the representative response was chosen by selecting the response from the more senior staff member (where identifiable) or, failing that, the response that was first received. These seven cases showed some discrepancies among responses, suggesting that a reporting bias may be present in other responses. ${ }^{5}$ These cases highlight a weakness in the collection method and in the data - namely, that what is reported by the councils may not be entirely accurate, an issue with any self-reporting method. There may also be issues with social desirability bias as respondents are keen to present their local governments in a favourable light. However, this finding also highlights the ambiguity of how community engagement is positioned and understood in organisations - an interesting result in itself. A final weakness of the data is that they provide a snapshot of practice at a particular time making, it difficult to assess trends.

\section{Findings}

\section{How often are councils engaging?}

Councils were asked to quantify approximately how many community engagement processes they had delivered in the previous 12 months. Responses ranged from none to (presumably) inaccurate outliers of 500 and 800 processes, as shown in Figure 3. The outliers, as well as some of the comments received in lieu of quantifiable amounts, highlight an important difficulty in researching community engagement practice: as one respondent stated, 'It depends on what level you are talking about. We conduct

\footnotetext{
${ }^{5}$ While many of the duplicate responses were similar, there was one extreme example where, for one metropolitan council Respondent A reported 12 processes in the previous year, all designed and planned by council staff, and the key barrier was the ineffectiveness of the community engagement staff. Responded B reported 48 processes in the previous year, with two-thirds designed and planned by council staff, and the key barrier was the lack of staff resources to stretch across the organisation.
} 
hundreds of engagements with documents on exhibition...[and]... about 30 community meetings'. This ambiguity is one that has been previously identified (Head 2007) and continues to create confusion within what we have delineated (above) as community engagement understood as an embedded practice. It is likely that responses include (for example) everything from public meetings to letter notifications, and may even include phone calls or community events. On the whole, however, the responses appear realistic if community engagement processes are interpreted as the as delivery of a number of methods or activities for one particular decision-making purpose, with the majority of councils undertaking between one and six processes every few months.

Figure 3 Estimated number of community engagement processes per council per annum (n=166)

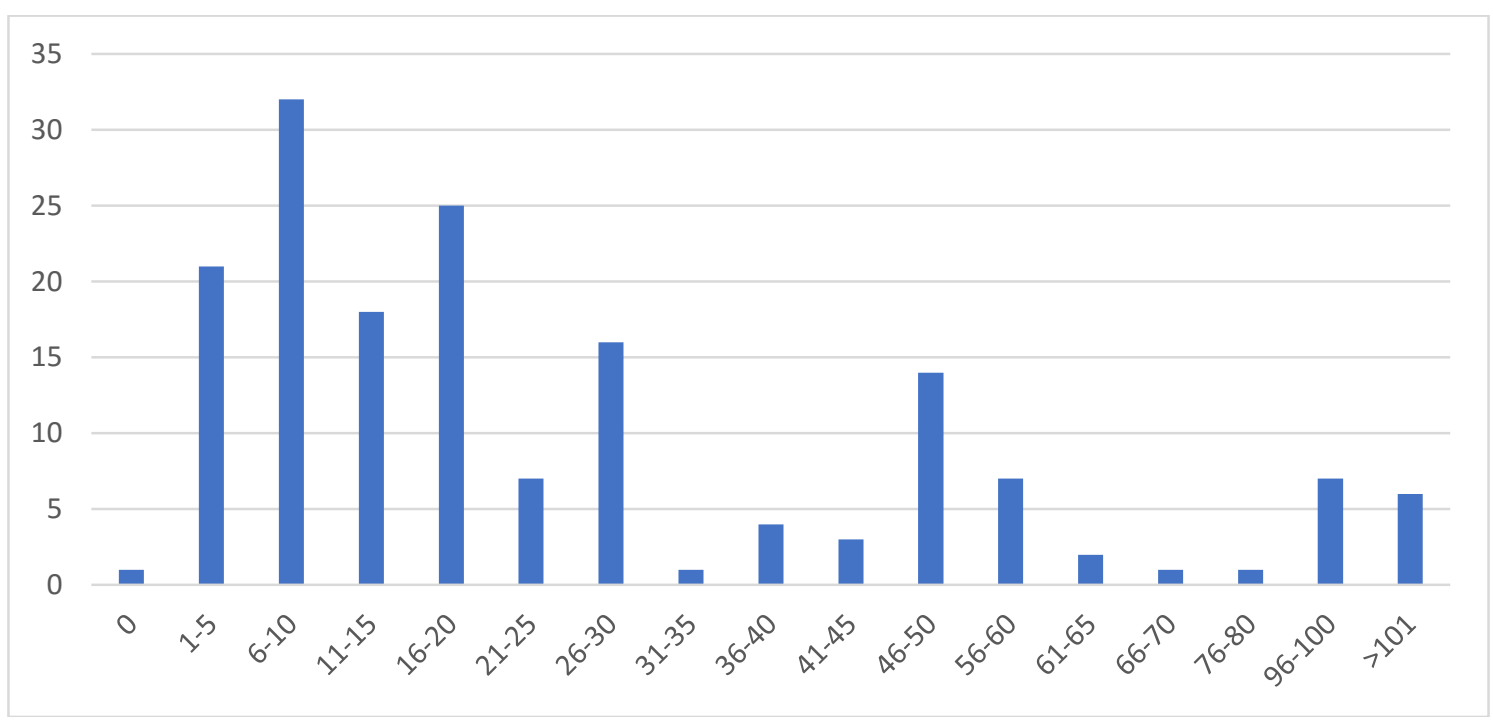


Figure 4 shows the average number of processes, excluding outliers, for all council types. The overall average is 29.4 processes per annum. More processes were reported in capital cities and metropolitan councils (averaging 44.1), than in urban regional councils (34.1) and urban fringe councils (29.4), and rural and remote councils (15.3).

\section{Figure 4 Mean estimated number of community engagement processes per council type per annum $(n=164)$}

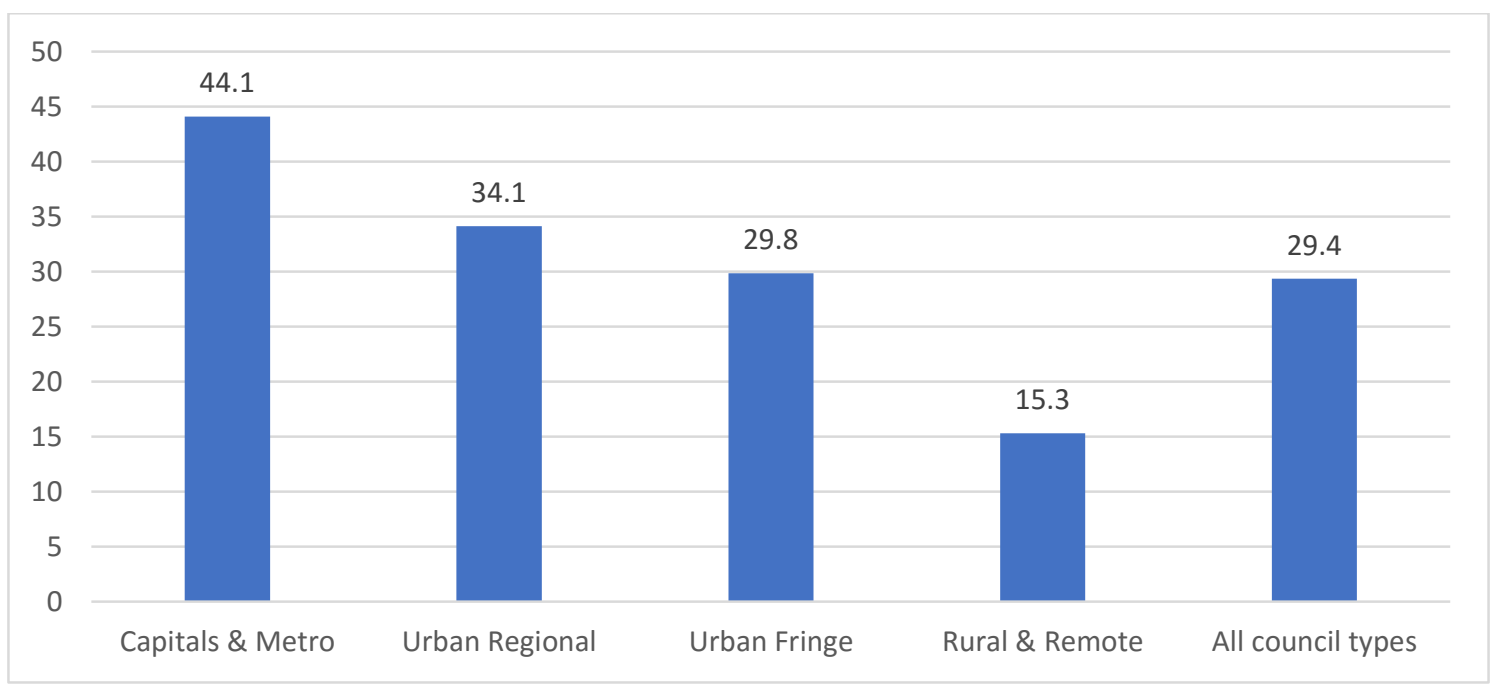

These observed differences are proven to be statistically significant using an ANOVA test. As the results indicate, the null hypothesis - which suggests that the mean number of community engagement processes are equal across the four council typeswas rejected at the $1 \%$ level of significance. A pairwise comparison (using the TukeyKramer procedure) identified that capital city and metropolitan as well as urban regional councils had significantly more processes than did their rural and remote counterparts. A difference in the number of processes was not observed among states, as the null hypothesis of equal process means could not be rejected $(\mathrm{p}=0.23>0.05)$. While it is not surprising that urban councils are engaging more frequently than their regional and remote counterparts, why this is the case warrants further research. Reasons may 
include greater funding, and therefore resources to undertake engagement in the urban areas; perhaps along with greater prevalence of activist groups. In the smaller regional and remote councils, there may be a high degree of informal social connection that does not warrant large formal engagement processes, or perhaps limited resourcing means that there are more significant priorities and capability issues (Morris 2012).

\section{How are councils engaging?}

As we have seen, local governments across Australia's jurisdictions are obliged to conform to a variety of requirements for community engagement, as dictated in relevant legislation and regulations, including - but not limited to - the relevant local government acts. The requirements vary among jurisdictions and range from stipulations to follow the council's public consultation policy, such as in South Australia, through to following public notification and submission processes, present in all of the current local government acts except for Queensland (Christensen forthcoming; Grant et al. 2011; Grant and Drew 2017). Legislative requirements to engage can be interpreted as the minimum requirements for councils.

To determine how councils were engaging, the census asked which community engagement methods councils have used in the past (12 months or more before the census), the present (current 12 months), and are intending to use in the future (the next year or beyond). Councils were surveyed on the use of 12 different methods, which are listed and grouped as follows:

- Traditional methods - those that are commonly associated with local government community engagement and participation: includes public meetings, public submissions, advisory/community reference groups 
- Contemporary methods - those that are more participatory than traditional methods and have become commonly associated with local government in more recent years: includes community summit/workshop ( $<30$ participants), community summit/workshop (>30 participants), drop in/open house/staffed display, focus groups

- Online methods - those that are conducted on web-based platform: includes online discussion forums and online surveys

- Deliberative methods - those that conform to principles of deliberative democracy: includes citizens' jury/deliberative panel/forum

- Emerging methods - those that are not yet commonly associated with local government but have had significant use in very recent years: includes: open space/unconference and participatory budgeting.

These methods were chosen to provide a sample of common methods; yet the list is by no means comprehensive or indicative of the suite of methods used by councils (Rowe and Frewer 2005). The list was refined in the testing of the survey and participants were invited to list any other regularly used methods, although these responses did not elicit any substantial findings. The findings are illustrated in Figure 5 (traditional methods), Figure 6 (contemporary methods), Figure 7 (online methods) and Figure 8 (deliberative and emerging methods).

Figure $5 \quad$ Traditional Method Use $(n=175)$ 
Public Submissions

Advisory/Community Reference Groups

Public Meetings

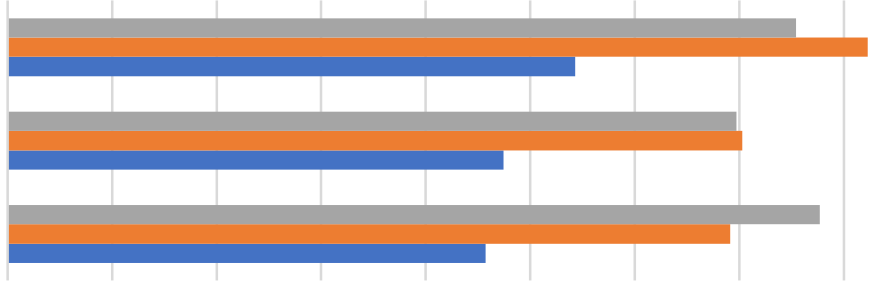

Past $\square$ Present $\square$ Future

$0 \quad 10$

20

30

Percent

Figure 6 Contemporary Method Use $(n=175)$

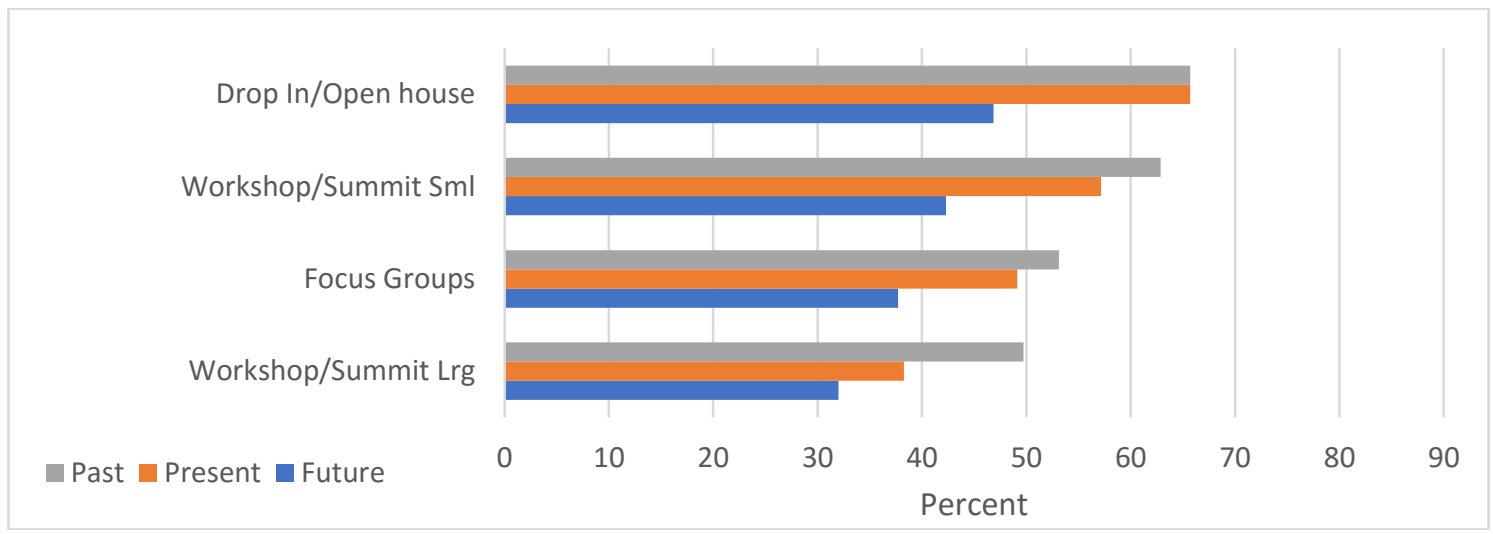


Figure $7 \quad$ Online Method Use $(n=175)$

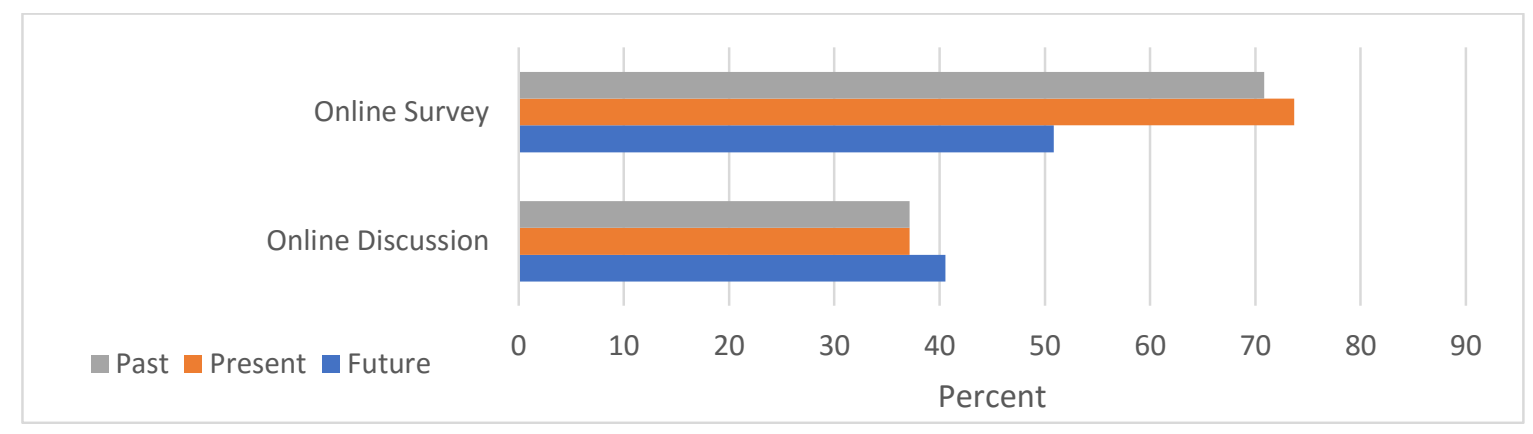

Figure 8 Deliberative and Emerging Methods Use $(n=175)$

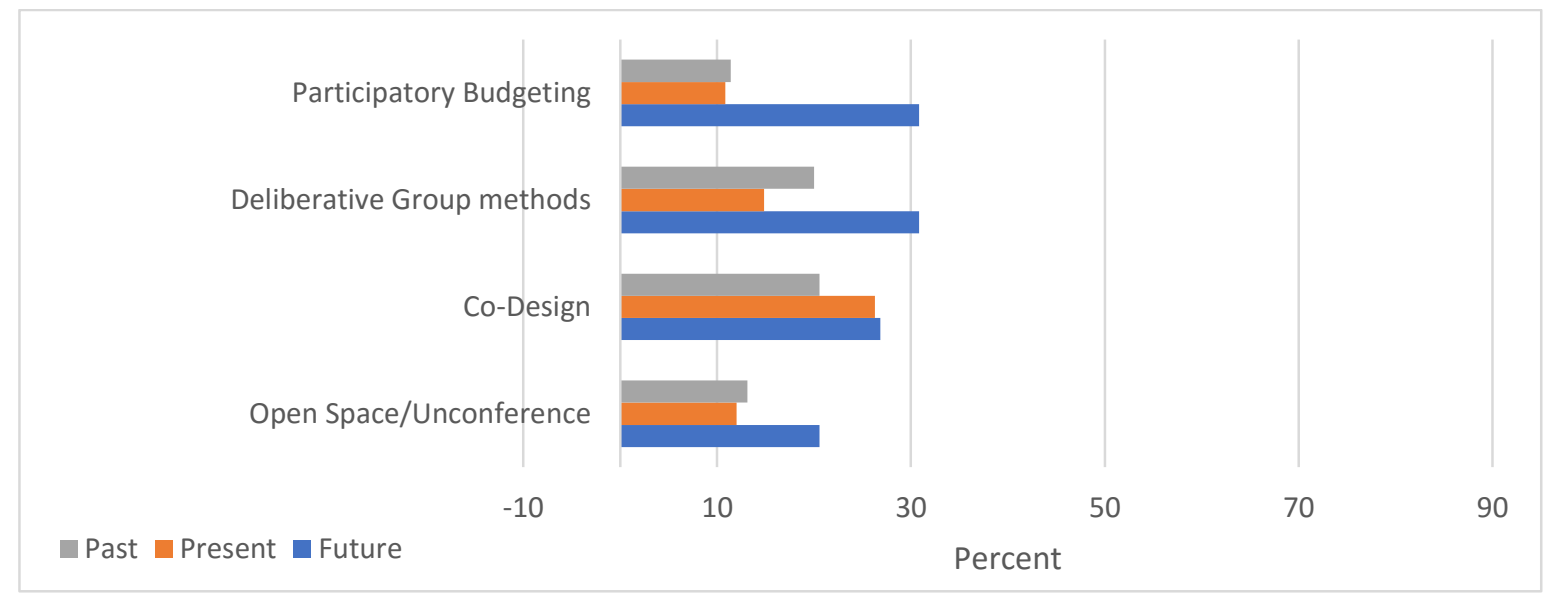

The data collected show that the traditional engagement methods of public meetings, public submissions and advisory/community reference groups (Figure 5), along with 'drop in' sessions (Figure 6) and online surveys (Figure 7), dominate the community engagement activities of local councils. These five methods were most frequently reported for past, present and future use, with $65 \%$ or more of councils reporting use of these five methods in both the previous and the current 12-month period.

Not surprisingly, public submissions (75.4\% past, $82.3 \%$ present, $54.3 \%$ future) remain popular, due to their extensive use in legislation (Christensen forthcoming). The process involves councils inviting written, and now sometimes electronic, submissions 
to object to or support proposals. Community members sometimes have the option to present their position at a council meeting and to receive a written response from the council.

Second only to public submissions in current use are online surveys (70.9\% past, $73.7 \%$ present, $50.9 \%$ future). The main appeal of this method is that the data collected are quantifiable and require minimal analysis for decision-making, and that they can be administered at a low cost (Sandoval-Almazan and Gil-Garcia 2012), especially when compared with face-to-face methods over geographically dispersed areas. Like other traditional methods, online surveys are likely to oversample active community members and lead to participation bias (Fung 2003), as well as failing to engage a more representative segment of the community (Leighninger 2011), thereby making it difficult for councils to make the best decision for the whole community.

Advisory/community reference groups (69.7\% past, $70.3 \%$ present, $47.4 \%$ future) also remain a well-established method amongst councils, again partly because of legislative requirements (Hendriks et al. 2013). These groups take a number of forms and are given various levels of decision-making authority depending upon their governing legislation and context (Bolitho 2013). In her study of citizen committees, Bolitho (2013) identified common frustrations with this method, such as integration with other council functions, ability to influence decision-making and a lack of both representativeness and operational effectiveness.

Public meetings (77.7\% past, $69.1 \%$ present, $45.7 \%$ future), or 'town hall' meetings as they are also known, are typically conducted in a format where officials and experts present the information and then the audience of community members and stakeholders can ask questions or make comments, sometimes with a time limit. With a long history 
of use in the United States (Bingham 2010) and Australia (Bishop and Davis 2002), this method is not currently stipulated in any of the local government legislation, although aspects are often incorporated into larger public submission processes. Despite its ongoing popularity, the method is now subject to increasing criticism for three main reasons: it fails to foster deliberation and generally fails to influence the public's decisions (Adams 2004; Bishop and Davis 2002: McComas et al. 2010; Wang 2001); it cannot accurately assess support or opposition to proposals, as attendance is dominated by 'usual suspects', 'angry mobs' and 'grandstanders' (Leighninger 2014; Working Group on Legal Frameworks for Public Participation 2013); and negative experiences can reduce political efficacy, social capital and public trust (Knight Foundation 2010; Leighninger 2014; Lukensmeyer 2013).

'Drop-in' sessions/open houses (65.7\% past, $65.7 \%$ present, $46.9 \%$ future) are often used as a less adversarial alternative to public meetings, as participants are invited to attend displays where council staff are present and where individual questions and concerns can be responded to in a one-on-one or small-group setting.

This preference for traditional engagement methods mirrors similar findings overseas (Nabatchi and Amsler 2014; Wang 2001; Wang and van Wart 2007), although surprisingly, councils are less committed to using these methods in the future. The sharpest decline is in the intention to use public meetings, with a $44.2 \%$ drop from past use to intended future use. Also interesting is the decline in the intention to use public submission processes (28.0\% drop from past to future use): this would indicate that councils are using the method even when not stipulated in the legislation, or that there may be an expectation that future legislation will require less or no use of this method.

Despite the domination of traditional methods, other types of engagement are 
also used frequently. What is particularly noteworthy is the reported use of deliberative and emerging methods. In the survey deliberative methods were described as 'Citizens' Juries, Deliberative Panels and Forums'. Past reported use was $20 \%$ of all councils, current use is $14.9 \%$ and future intended use is more than twice that at $30.9 \%$.

Furthermore, emerging methods have a similar reported use, with nearly onethird $(30.9 \%)$ of councils intending to use participatory budgeting in the future, despite only $10.9 \%$ using it in the current year and $11.9 \%$ reporting its use in the past. This is especially noteworthy, given that participatory budgeting processes have been used in Australian local governments only in the past five years (Christensen and Grant, 2016).

Co-design processes are also experiencing a similar trend, with one-fifth (20.6\%) of councils reporting use in the past and just over a quarter reporting use in the present $(26.3 \%)$ and intended future use $(26.9 \%)$. Co-design was included in the census in response to the revival of co-production, co-delivery, co-commissioning and other joint state-public approaches to service and program design and delivery (see Alford and Yates 2016; Bovaird 2007; Bovaird and Loeffler 2013; Nabatchi et al. 2017; Voorberg et al. 2015). Arguably, the term 'co-design', together with its related umbrella terms, is poorly defined and loosely applied (Nabatchi et al. 2017), making it difficult to know if councils understand this method as a way of working or as a deliberative practice.

Despite the clear differences among the individual methods of community engagement used by councils, no significant difference was found among the council categories, or among the states surveyed ( $\mathrm{p}=0.88$ and 0.97 , respectively). In conjunction with the descriptive analysis above, this indicates that, although councils show preferences for certain methods of community engagement (including public 
submissions, online sessions, and drop-in sessions), individual methods are not employed more or less by particular council types, or within particular states. Rather, we observe a relatively uniform approach to community engagement.

\section{What is driving community engagement by councils?}

Respondents were asked what they believed was driving community engagement practice in their local governments, and were provided with a number of options to rank. As shown in Figure 9, the highest ranking response was 'Known effectiveness in assisting with decisions' (27.6\%), followed by 'Statutory requirements' $(21.8 \%)$ and 'Enthusiasm and demand from the public' (18.4\%). When asked if there were any additional reasons or drivers, a quarter $(25.3 \%, \mathrm{n}=44)$ of participants responded. These included (in order of frequency): enthusiasm/demand from executive staff, 'best practice', council policy, recent amalgamations/reforms, risk and reputation management, aligning provision with needs of changing community, and building relationships and capacity with community.

Whilst the responses chosen did not vary significantly by council type $(\mathrm{p}=0.171)$, some states were found to have a statistically significant impact on the factors deemed important (at the $1 \%$ level). In particular, a significantly higher proportion of councils in Queensland and Victoria deemed that 'Enthusiasm and demand from the public' was a key or primary driver of community engagement, compared with councils in New South Wales and South Australia (which viewed the effectiveness of community engagement as assisting decision-making, and the ability to deliver on corporate strategies and policies as the main drivers). Moreover, 'Statutory requirements' were also deemed less important in Victoria (with only $10 \%$ ranking these requirements as the primary driver) compared with their South Australian 
counterparts.

Figure 9 Highest-ranked driver for community engagement practice in local government $(n=174)$

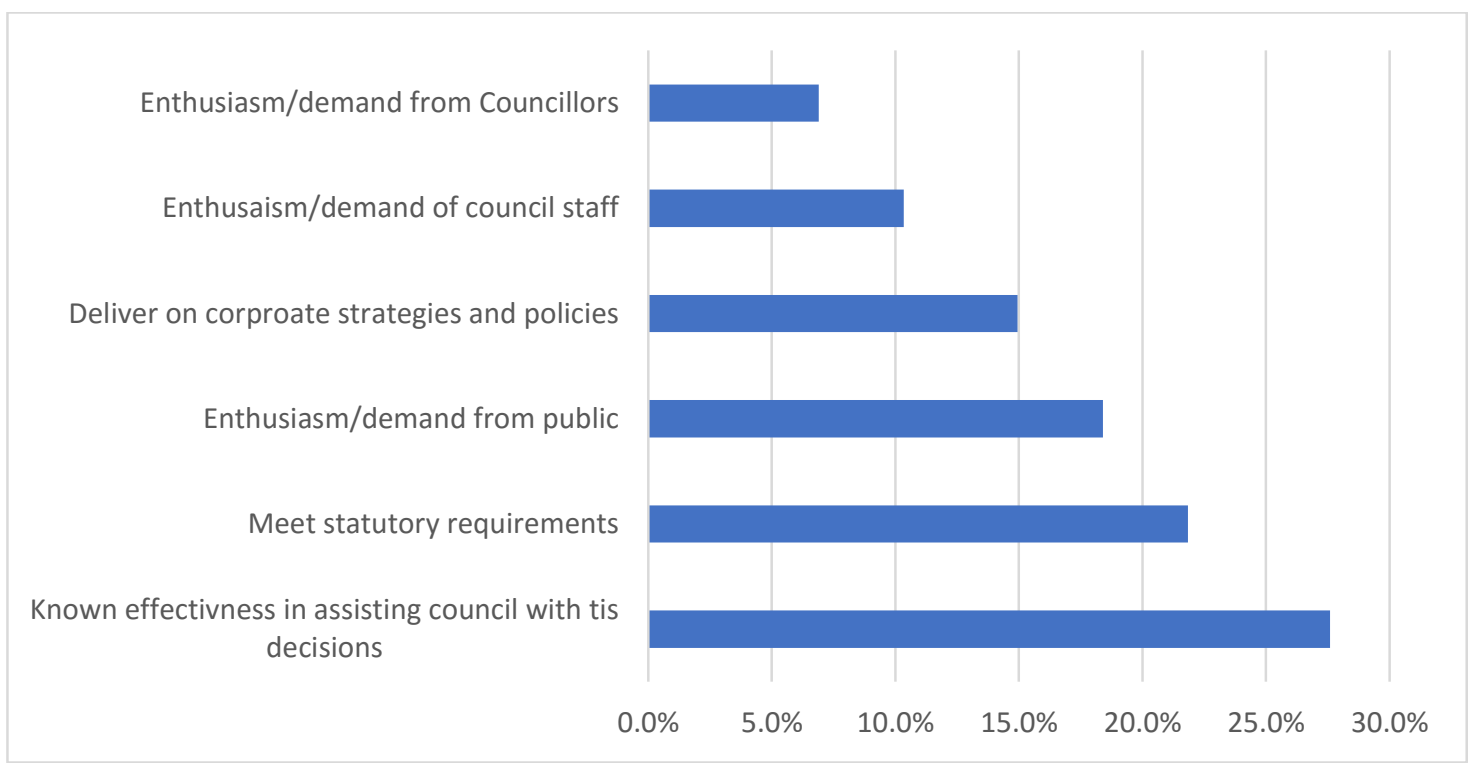

\section{Who is designing and delivering local government community engagement processes?}

Given that all councils surveyed are delivering community engagement processes, a logical question is: who is planning, delivering, reporting and evaluating these processes? Consequently, councils were asked who was responsible for the planning and delivery of community engagement in their organisation. As Figure 10 shows, nearly half (46.9\%) of councils have an arrangement where relevant staff, presumably from different work areas such as land use planning, community services, and environmental services, work with specialist staff to plan and deliver processes. The second most common arrangement was planning and delivery by relevant staff $(26.9 \%)$. Other arrangements include centralised specialist staff arrangements (9.7\%) and relevant staff working with an executive staff member (1.17\%). 


\section{Figure $10 \quad$ Internal responsibility for planning and delivery of community engagement $(n=175)$}

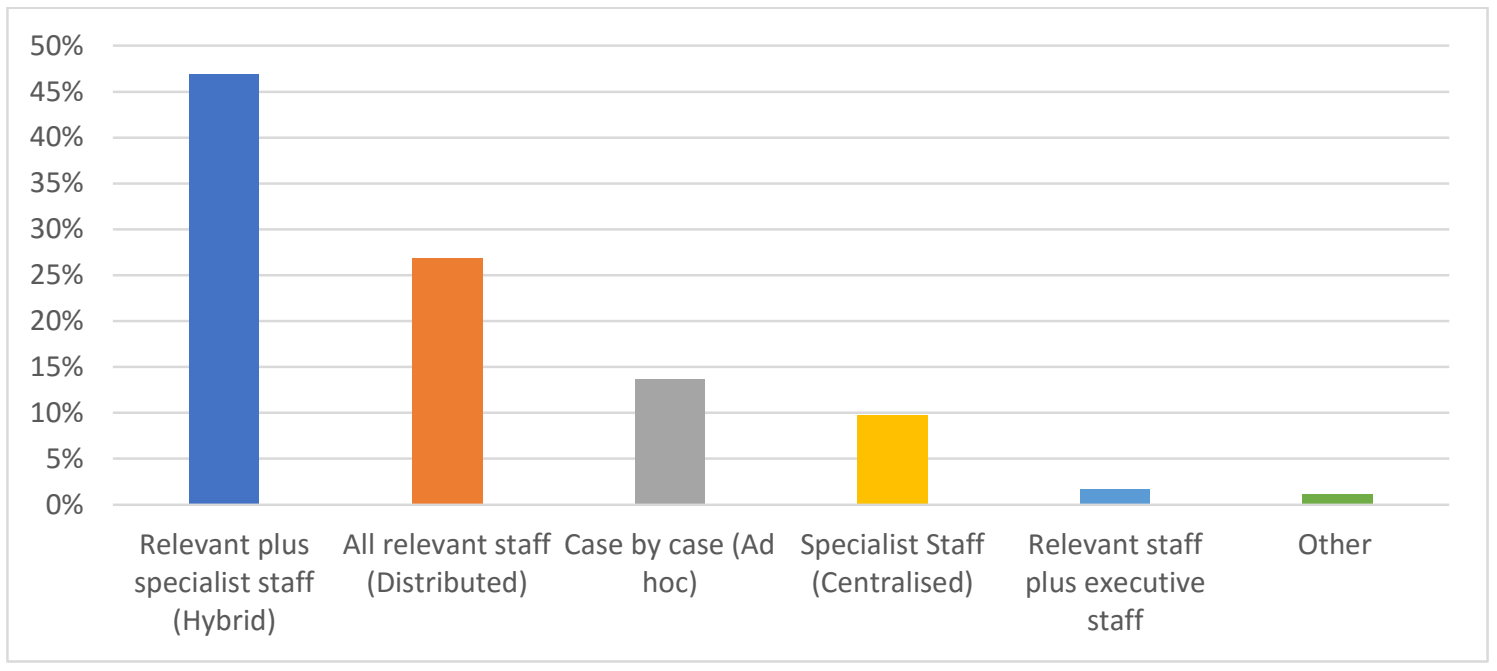

These findings are noteworthy for two reasons. First, in the instances where relevant staff are wholly or partly responsible, the arrangement assumes that, regardless of disciplinary background and area of expertise, local government staff are expected to have a degree of understanding and involvement in the planning and delivery of community engagement. This in turn suggests that the knowledge and skills for planning and delivering community engagement are either assumed to be intrinsically known, previously acquired, acquired on the job, a combination of these or, alternatively, that no specialist knowledge and skills are required. Second, in most councils, staffing arrangements do not extend to include specialist community engagement staff.

In order to explore where these differences occur, Figure 11 shows the same data by council type. Not surprisingly, given size and staffing constraints, all council types, except rural and remote, are likely to use a hybrid arrangement (capitals and metropolitan 58.3\%, urban regional 55.9\%, urban fringe $85.7 \%$ ). Rural and remote councils were significantly less likely (at the $1 \%$ level) to use a hybrid arrangement for planning and delivery of community engagement, with statistically higher proportions 
of these councils choosing an ad hoc or distributed arrangement (compared with their urban regional counterparts). Like the individual council types, the arrangements used by councils in different states also varied substantially. Whilst New South Wales and Queensland had significantly higher proportions of councils employing a centralised arrangement, Queensland councils were significantly less likely to use a distributed arrangement, compared with councils in Victoria.

Figure 11 Internal responsibility for planning and delivery of community engagement by council type $(n=175)$

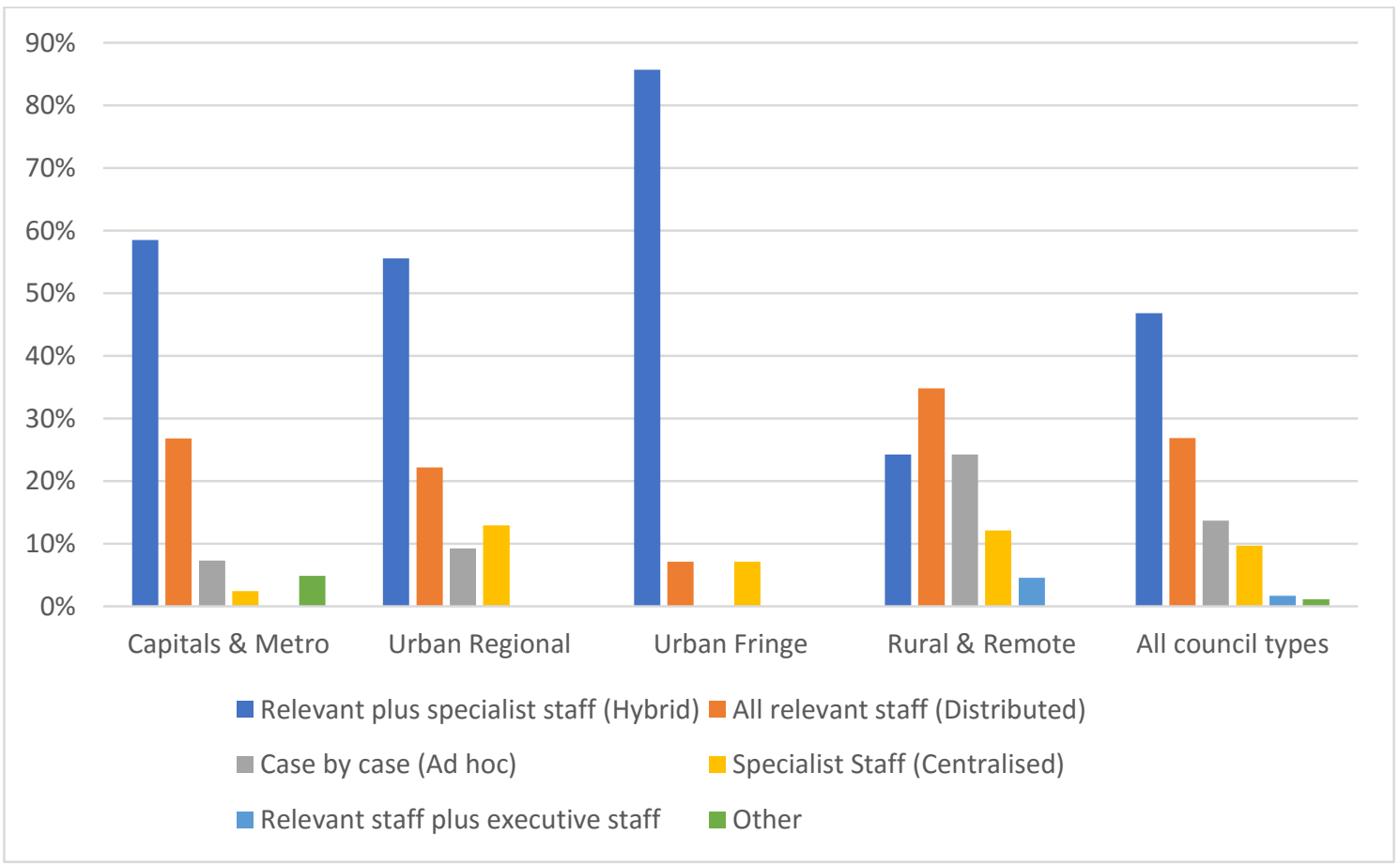

While there are relatively high proportions of specialist staff in urban regional (11.9\%), urban fringe (12.1\%) and rural and remote $(9.7 \%)$ councils, it is likely that these staff are not dedicated community engagement staff and may be part positions. This can be inferred from the results to the next question.

Survey respondents were asked how many staff in their councils had roles 
dedicated only to community engagement. The question stipulated that these staff positions not be combined with other functions such as communications. The results are in presented in Figure 12 and illustrate that half of the councils do not have a dedicated community engagement staff member and, for those that do, the number of staff ranges from 0.3 to 20 .

Figure 12 Estimated number of dedicated community engagement staff per local government $(n=175)$

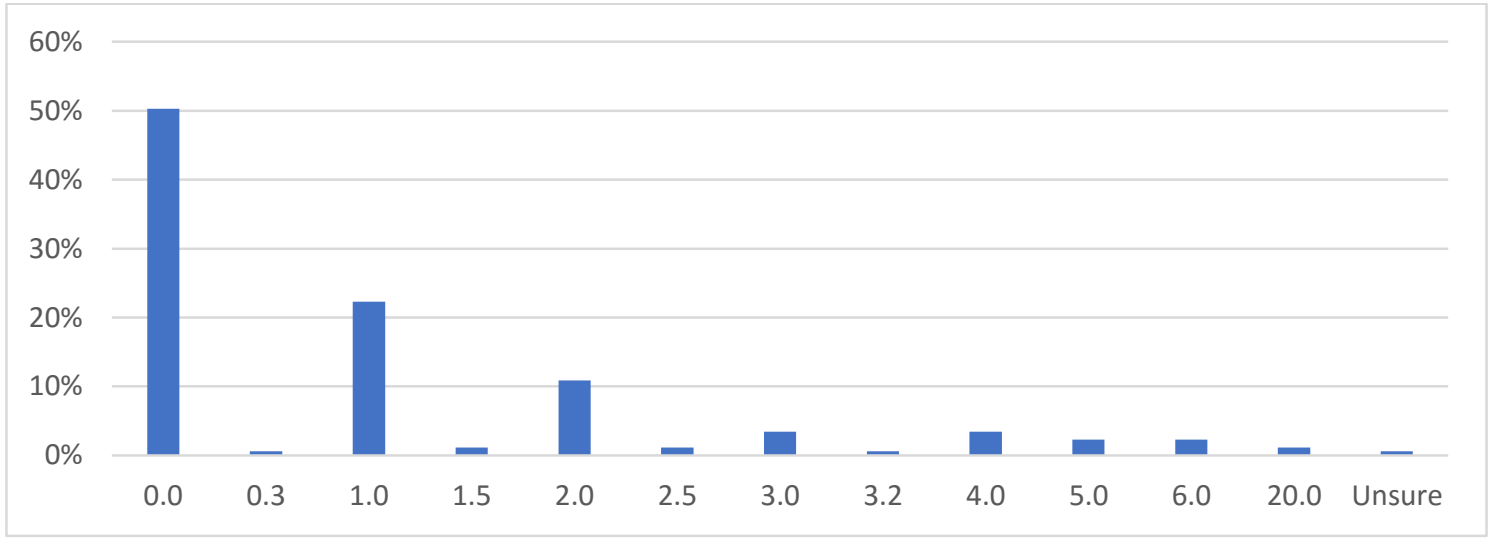

The average number of community engagement staff members in the organisation was 1.23 across all councils, and 2.49 in those organisations with dedicated community engagement staff. Figure 13 highlights the differences in the mean number of community engagement staff among council types and states. Although the differences among states were not significant, capital and metropolitan councils had significantly higher levels of dedicated staff than their rural counterparts (at the $1 \%$ significance level). However, if the sample is restricted to exclude councils without dedicated staff, this difference disappears, due primarily to the comparably large number of rural and remote councils without dedicated community engagement staff. 


\section{Figure 13 Average numbers of dedicated community engagement staff across council types and states $(n=174)$}

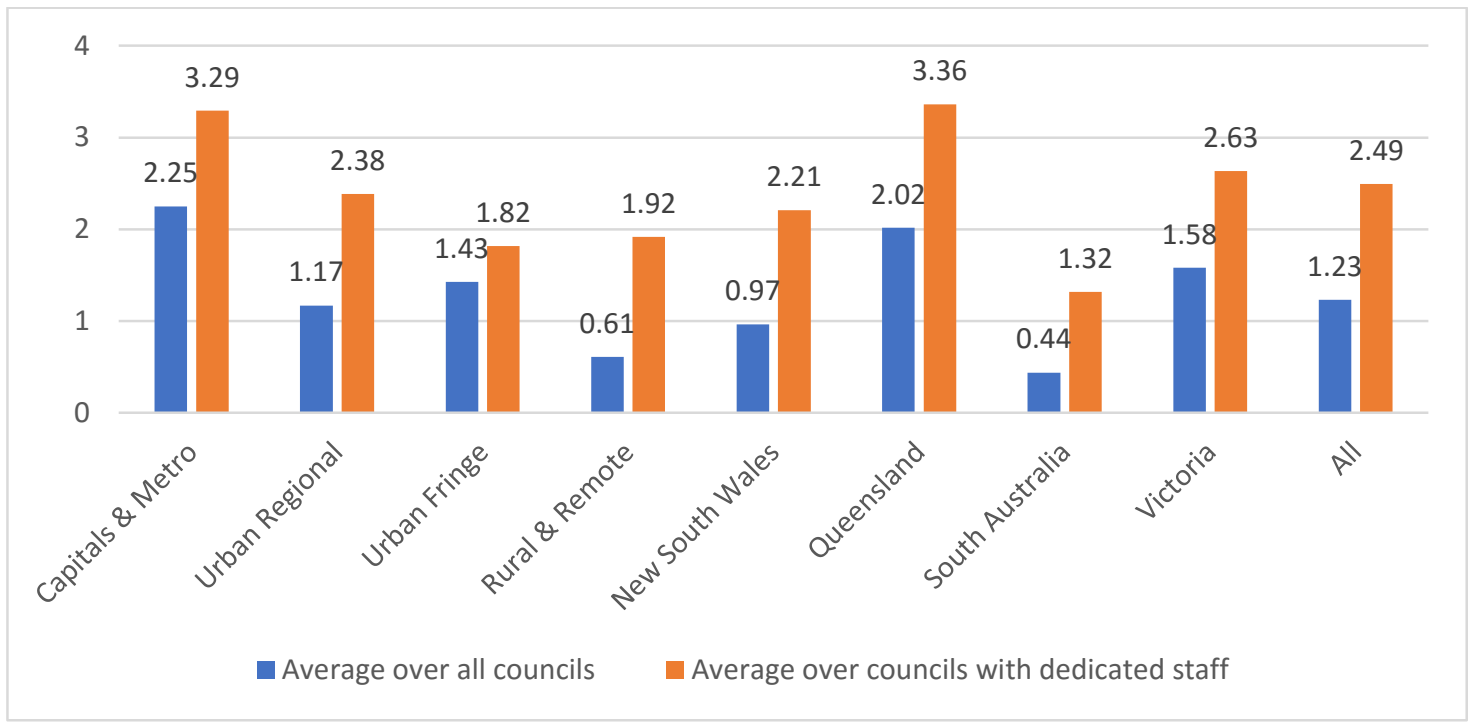

In the instances where a council has no dedicated community engagement staff but employs other specialist staff to assist with community engagement, it can be assumed that the community engagement function is being combined with another work function such as communications or community development. If community engagement is positioned alongside other work functions, it is likely to impact how it is understood in the organisation and how it is practiced. For example, is community engagement seen as an extension of governance and corporate strategy? Is it part of community development? Is it seen as a form of research? Or a form of communications? Or public relations by a different name?

To explore this respondents were asked 'Where is community engagement positioned in your organisational chart?' Congruent with the earlier findings where councils had no dedicated staff and responsibility for planning and delivery sat with relevant staff, $26.9 \%$ of councils indicated that there was no specific work area for community engagement. This finding is illustrated in Figure 14, along with the position 
of community engagement in other councils. Of significance is the result that $25.1 \%$ of councils combine the community engagement work function with communications, media and/or public relations. While in many councils these fields are perceived as the most complementary and compatible, the differences among them might have more of a negative impact upon community engagement than upon communications, as community engagement is likely to be the less dominant field. For example, if the focus of a community engagement process is on communications or information sharing it might neglect the decision-making aspect, rendering the engagement tokenistic.

\section{Figure 14 Organisational position of community engagement (n=175)}

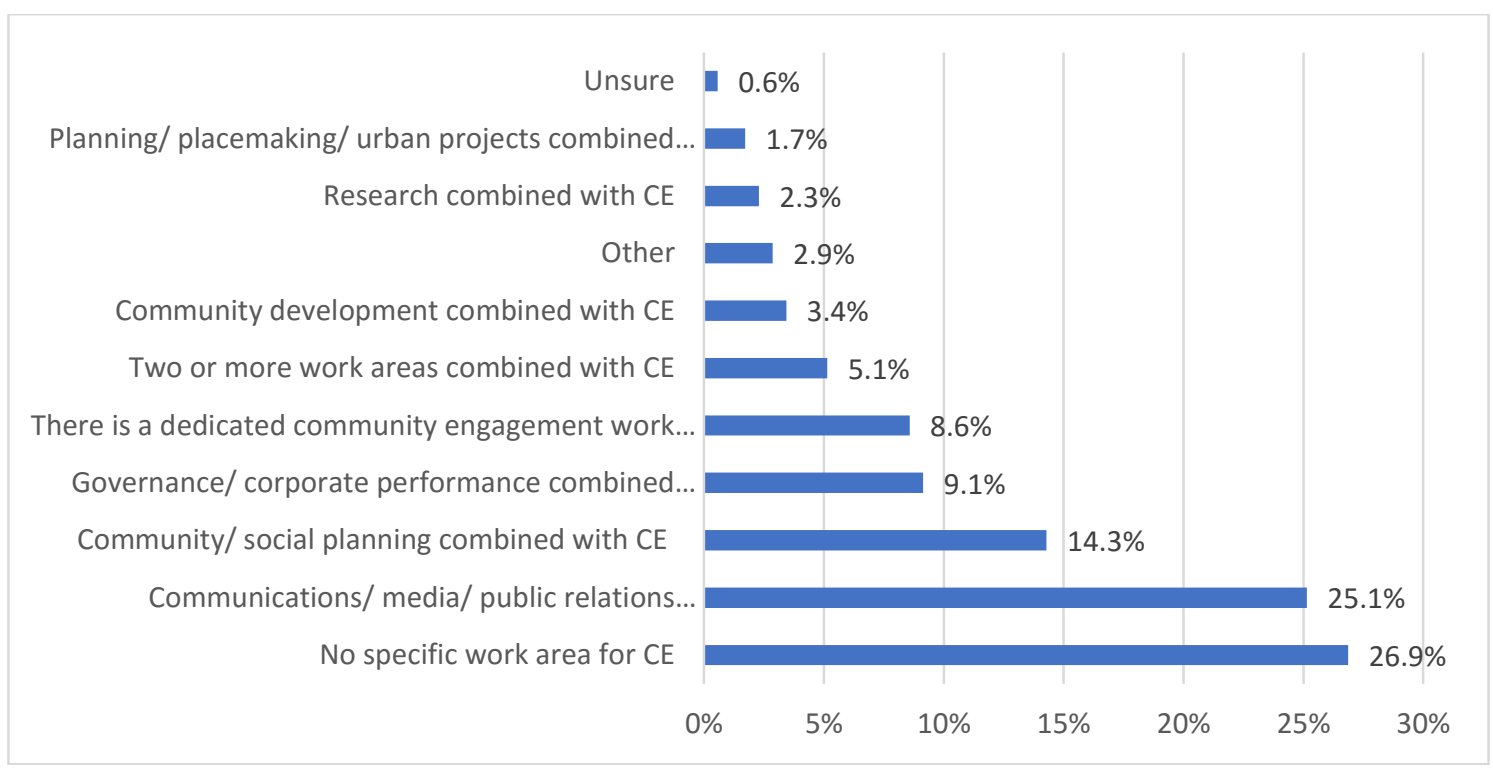

Only $9.1 \%$ of councils reported combining community engagement with their governance functions. This is notable, as community engagement is widely understood to be the involvement of the community in the decision-making, and formal decisionmaking processes, such as public submission processes, are often managed by the governance work areas as they usually have oversight for legislative compliance. Other work areas with which community engagement is combined include: community/social 
planning (14.3\%), community development (3.4\%), research (2.3\%) and planning/place-making/urban projects (1.7\%). Only 5.1\% of councils include multiple functions alongside community engagement.

Similar to the stark differences in the position of community engagement within councils, a significant difference is observed among council types and states. In the rural and remote, and urban regional council categories, which have a higher proportion of councils without dedicated community engagement staff, a significantly higher proportion have no specific work area for community engagement (at the $1 \%$ level). In regard to the states, significantly fewer councils in South Australia (indeed, none of the councils) combine their community engagement activities with their community and/or social planning functions, compared with $22 \%$ of councils in both Queensland and Victoria. ${ }^{6}$ Rather, similar to the rural and remote, and urban regional council categories, over $40 \%$ of South Australian councils have no specific area for community engagement.

Local government is a significant client group for the growing industry of community engagement consultants (see Bherer et al. 2017; Hendriks and Carson 2008; Lee 2015). Consequently, census respondents were asked to estimate how much community engagement they plan and deliver as an organisation, in contrast to that which is planned and delivered by external consultants. The results are presented in Figure 15 and show that roughly one-fifth (22.9\%) of councils do all their own planning and delivery. Nearly two-thirds (62.3\%) plan and deliver two-thirds or more themselves, $10.3 \%$ do about half and $4.0 \%$ do up to a third. Through hypothesis testing it is evident that both fringe, and rural and remote councils are significantly less likely

\footnotetext{
${ }^{6}$ At the $1 \%$ and $5 \%$ significance levels, respectively
} 
than capital and metropolitan, and urban regional councils to plan and deliver more than two-thirds of their community engagement processes (at a 5\% level). Only $35 \%$ of fringe and $46 \%$ of rural and remote councils provide over two-thirds of processes (but not all processes), compared with $75 \%$ of capital and metropolitan, and $77 \%$ of urban regional councils. Rather, rural and remote councils are significantly more likely to plan and deliver the entire process themselves (with $36 \%$ choosing this option), whilst fringe councils are more likely to plan and deliver all processes (29\%) or half of the processes (21\%) themselves, although this is not statistically significant.

Figure 15 Estimated proportion of community engagement processes designed and delivered by local government staff $(n=175)$

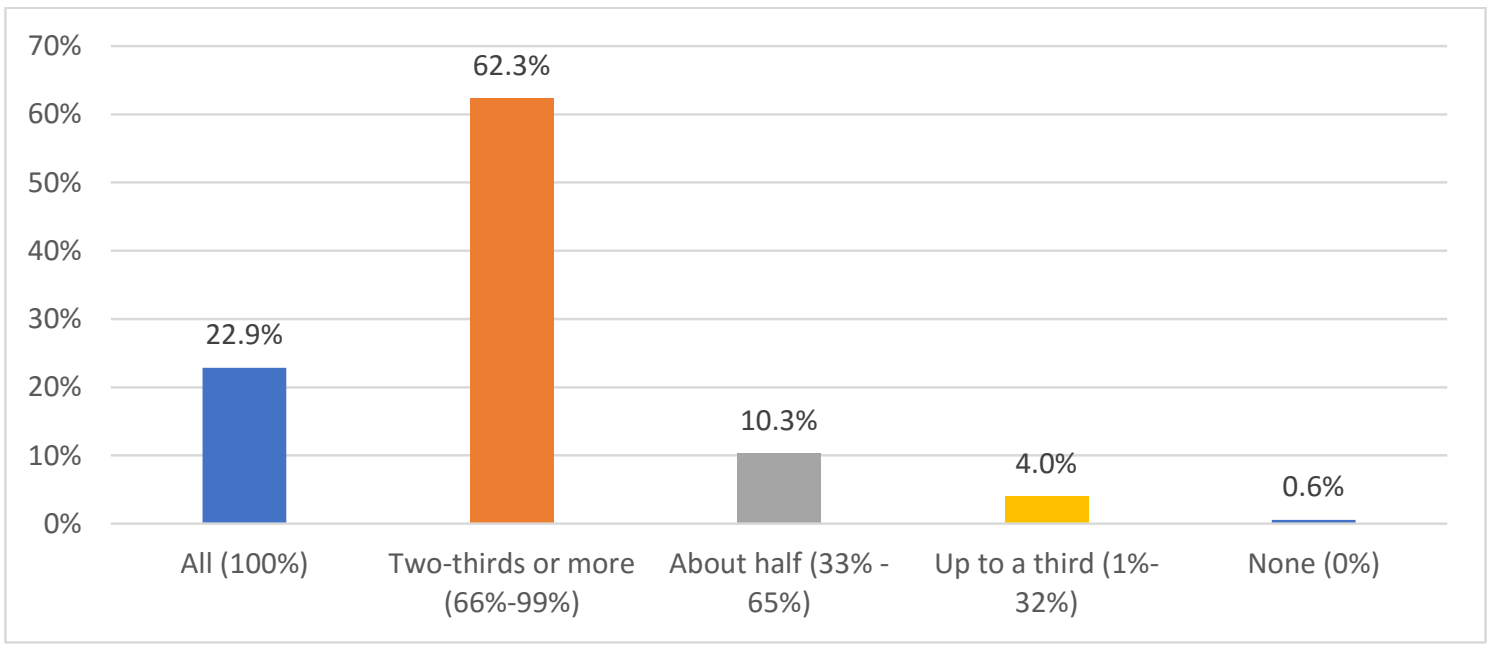

What are the challenges for councils in delivering community engagement?

The final question asked what respondents believed were the main difficulties in delivering community engagement processes in their local government. Over a third $(37.1 \%)$ cited the time required, which suggests problems of being under-resourced and/or poor planning. Nearly a quarter $(23.4 \%)$ cited public interest, although with hindsight this response should have stipulated 'poor public interest' or 'high public 
interest'. Lack of budget was cited by $14.4 \%$, also suggesting a problem with resourcing. Other reasons given were knowledge and skills of staff (8.4\%), executive leadership commitment (9.0\%), councillor support (5.4\%) and statutory requirements (2.4\%). Again, the results obtained in this question did not differ significantly by council type $(\mathrm{p}=0.322)$ or state $(\mathrm{p}=0.649)$. The problems of limited time, resources, staff skills, leadership commitment are probably not isolated to particular types of councils or to individual states (for instance, it is not unreasonable to suggest that councils can experience the problems of insufficient time and financial resources available for community engagement regardless of the characteristics of the council).

When asked if there were any additional difficulties, $43.5 \%$ of respondents who answered the question noted other points. In order of frequency, these included geographical disbursement of community (33.3\% of additional comments), poor telecommunications infrastructure (12.1\% of additional comments) and, each with less than $5 \%$ frequency, lack of dedicated staff, over-consultation or consultation fatigue, difficult community members, apathy, engaging hard-to-reach groups, poor planning and staff commitment/enthusiasm.

Figure 16 Highest ranked difficulties in delivering community engagement $(n=167)$ 


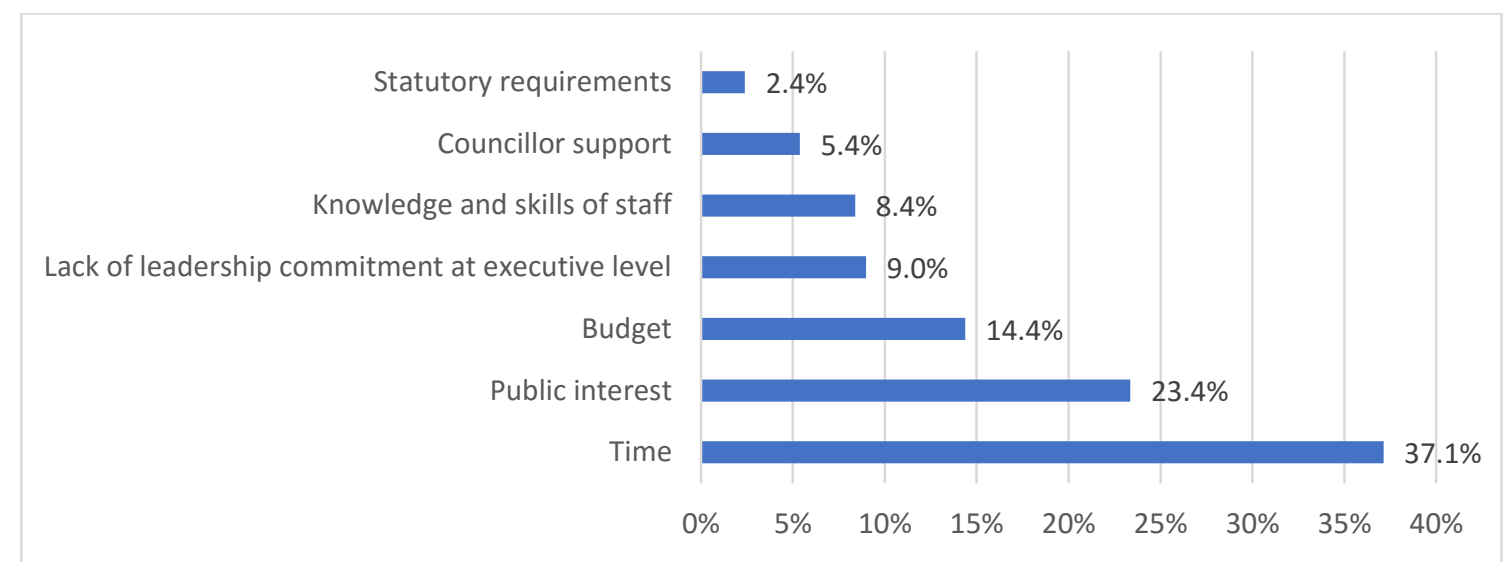

\section{Summary and future research}

Against the backdrop of three broad approaches to community engagement in the scholarly literature which we defined as $a$ priori theoretical, an institutional approach and an embedded approach, this paper has presented the findings of a census probing community engagement practice in Australian local government. These initial findings show that community engagement practice has been subject first and foremost to legislative requirements, as demonstrated through the dominance of traditional methods. These methods are usually legislated (such as public submission), inexpensive to deliver (such as online surveys). However, these methods are not without their problems, which may explain the decline in intended future use, with respondents reporting a planned shift to more innovative and emerging methods. The highest reported driver for community engagement practice is its known effectiveness for assisting in decisionmaking, and the highest reported challenge in planning and delivering community engagement is the time required. The profile and resourcing of community engagement in local councils varies, and there is a significant coupling of a council's community engagement function with its communications, media and public relations functions. These findings suggest that community engagement is progressing in different directions, and that these directions depend not only on the jurisdictional legislative requirements but also on individual councils and their understanding of the role of 
community engagement, their leadership in this area and, undoubtedly, the resources they have available.

Returning to the three approaches to community engagement delineated in the scholarly literature, several points are salient. First, there is value in empirical inquiries, such as this one, informing theoretical discussions. For example, the importance of community engagement is likely to be elevated in contexts where other forms of democracy, such as voting, are less firmly established and (possibly) where local government areas are larger and where representation is a consequence of increased size (typically through consolidation of the perceived threat thereof — see Grant et al. 2012). Second, it is clear from the census that compliance is a main driver for community engagement, highlighting the relevance of the institutional approach. Third, the census shows us that practice does vary between local governments. Regardless of the perceived legitimacy of some practices compared with others at the theoretical level (for example, participatory versus deliberative versus collaborative governance — see Christensen and Grant 2016), local governments are able to practise community engagement in ways that are appreciative of the characteristics of their local communities. They can also learn from different practices in different places and innovate to tailor engagement for their communities. This accommodation of variance across different types of local governments, as well as the capacity for learning and innovation, conform to the traditional theoretical defences of local government (see Mill 1861 (1972); Tiebout 1956).

These findings assist in creating an understanding of the current practice in Australian local governments; however, the data raise additional questions, such as: Why is there declining interest in traditional methods? What is the appeal of emerging methods? What impact do specialist community engagement staff have on practice? 
What are the effects of positioning community engagement in different areas of the organisation? What is the role of external consultants in community engagement? These questions ought to be explored in future research. 


\section{REFERENCES}

Adams, Brian. 2004. "Public Meetings and the Democratic Process." Public Administration Review 64 (1): 43-54.

Adams, David, and Michael Hess. 2001. "Community in Public Policy: Fad or Foundation?” Australian Journal of Public Administration 60 (2): 13-23.

Alford, John, and Sophie Yates. 2016. "Co-Production of Public Services in Australia: The Roles of Government Organisations and Co-Producers." Australian Journal of Public Administration 75 (2): 159-175.

Ansell, Chris, and Alison Gash. 2008. "Collaborative Governance in Theory and Practice.” Journal of Public Administration Research and Theory 18 (4): 543-571.

Arnstein, Sherry R. 1969. “A Ladder Of Citizen Participation.” Journal of the American Institute of Planners 35 (4): 216-224.

Aulich, Chris. 2009. "From Citizen Participation to Participatory Governance in Australian Local Government.” Commonwealth Journal of Local Governance 2: 44-60.

Bherer, Laurence, Mario Gauthier, and Louis Simard. 2017a. "Who's the Client? The Sponsor, Citizens, or the Participatory Process? Tensions in the Quebec (Canada) Public Participation Field." In The Professionalization of Public Participation, edited by Laurence Bherer, 87-114. New York: Routledge.

Bingham, Lisa Blomgren. 2010. The Next Generation of Administrative Law: Building the Legal Infrastructure for Collaborative Governance. Research Paper 2010-07-04. School of Public and Environmental Affairs Indiana University. http://ncdd.org/rc/wpcontent/uploads/2010/09/Bingham-LegalInfrastructureWisc2010.pdf.

Bishop, Patrick, and Glyn Davis. 2002. "Mapping Public Participation in Policy Choices.” Journal of Public Administration 61 (1): 14-29.

Bolitho, A. 2013. The Role and Future of Citizen Committees in Australian Local Government. Sydney: Australian Centre of Excellence for Local Government. https://opus.lib.uts.edu.au/bitstream/10453/42125/3/ACELG_Citizen_Committees_Rep ort_.pdf.

Bovaird, Tony. 2007. "Beyond Engagement and Participation: User and Community Coproduction of Public Services.” Public Administration Review 67 (5): 846-860.

Bovaird, Tony, and Elke Loeffler. 2013. We're All in This Together: Harnessing User and Community Co-Production of Public Outcomes. Birmingham, UK: University of Birmingham, Institute of Local Government Stuides.

Bryson, John M., Kathryn S. Quick, Carissa Schively Slotterback, and Barbara C. Crosby. 2013. "Designing Public Participation Processes." Public Administration Review 73 (1). Wiley Subscription Services, Inc: 23-34. 
Bua, Adrian, and Oliver Escobar. 2018. "Participatory-Deliberative Processes and Public Policy Agendas: Lessons for Policy and Practice.” Policy Design and Practice, May. Routledge, 1-15.

Carson, Lyn, and Janette Hartz-Karp. 2005. "Adapting and Combining Deliberative Designs: Juries, Polls and Forums." In The Deliberative Democracy Handbook, edited by John Gastil, 120-138. San Franscisco: Jossey-Bass.

Cavaye, J. 2004. "Governance and Community Engagement - The Australian Experience." In Participatory Governance, Planning, Conflict Mediation and Public Decision-Making in Civil Society, edited by W. R. Lovan, M. Murray, and R. Shaffer, 85-102. Ashgate Publishing.

Christensen, Helen E., and Bligh Grant. 2016. "Participatory Budgeting in Australian Local Government: An Initial Assessment and Critical Issues." Australian Journal of Public Administration 75 (4): 457-475.

Christensen, Helen E. Forthcoming. "Prescribing, Aspiring, Empowering and Hedging: How Australia's State Governments Legislate Community Engagement at the Local Level." Commonwealth Journal of Local Governance.

Dean, Rikki John. 2016. "Beyond Radicalism and Resignation: The Competing Logics for Public Participation in Policy Decisions." Policy and Politics. doi:10.1332/030557316X14531466517034.

Department of Infrastructure and Regional Development (DIRD) (Australian Government). 2017. Local Government National Report 2014-2015. Canberra: DIRD.

Fung, Archon. 2003. "Survey Article: Recipes for Public Spheres: Eight Institutional Design Choices and Their Consequences." The Journal of Political Philosophy 11 (3): 338-367.

Fung, Archon. 2006. "Varieties of Participation in Complex Governance." Public Administration Review 66 (December). Blackwell Publishing Inc: 66-75.

Fung, Archon. 2015. "Putting the Public Back into Governance: The Challenges of Citizen Participation and Its Future.” Public Administration Review 75 (4): 513-522.

Fung, Archon, and Erik Olin Wright. 2003. Deepening Democracy - Institutional Innovations in Empowered Participatory Governance. London: Verso.

Gollagher, Margaret, and Janette Hartz-Karp. 2013. "The Role of Deliberative Collaborative Governance in Achieving Sustainable Cities." Sustainability: Science Practice and Policy 5 (6): 2343-2366.

Grant, Bligh, Brian Dollery, Michael Kortt, Joel Byrnes, and Lin Crase. 2011. Australian Local Government and Community Engagement: Are All Our Community Engagement Plans the Same? Does It Matter? Working Paper Series 05-2011. Centre for Local Government, University of New England. 
Grant, Bligh, Brian Dollery, and Gert van der Westhuizen. 2012. "Locally Constructed Regionalism: The City of Greater Geraldton, Western Australia". Public Policy 7(1):79-96.

Grant, Bligh, and Joseph Drew. 2017. "Community and Community Engagement in Australian Local Government." In Local Government in Australia, 217-264. Singapore: Springer.

Hartz-Karp, Janette. 2012. "Laying the Groundwork for Participatory Budgeting Developing a Deliberative Community and Collaborative Governance: Greater Geraldton, Western Australia.” Journal of Public Deliberation 8 (2): 1-18.

Haus, Michael, and David Sweeting. 2006. "Local Democracy and Political Leadership: Drawing a Map". Political Studies 54: 267-288.

Head, Brian W. 2007. "Community Engagement: Participation on Whose Terms?" Australian Journal of Political Science 42 (3): 441-454.

Head, Brian W. 2011. "Australian Experience: Civic Engagement as Symbol and Substance.” Public Administration and Development 31 (2): 102-112.

Hendriks, Carolyn M., Annie Bolitho, and Chad Foulkes. 2013. "Localism and the Paradox of Devolution: Delegated Citizen Committees." Policy Studies 34 (5-6): 575591.

Hendriks, Carolyn M., and Lyn Carson. 2008. "Can the Market Help the Forum? Negotiating the Commercialization of Deliberative Democracy." Policy Sciences 41 (4). Springer US: 293-313.

International Association of Public Participation (IAP2). 2014. "IAP2's Public Participation Spectrum."

http://c.ymcdn.com/sites/www.iap2.org/resource/resmgr/imported/IAP2\%20Spectrum vertical.pdf.

International Association for Public Participation (IAP2). 2018. "International Association for Public Participation.” Accessed August 22. http://www.iap2.org/.

Knight Foundation. 2010. "Knight Soul of the Community 2010: Why People Love Where They Live and Why It Matters: A National Perspective." http://s3.amazonaws.com/nei0615-p001/resources/soul-of-the-community---overall.pdf.

Lee, Caroline W. 2015. Do-It-Yourself Democracy: The Rise of the Public Engagement Industry. New York: Oxford University Press.

Leighninger, Matt. 2011. "Using Online Tools to Engage-and Be Engaged by-the Public." http://faculty.cbpp.uaa.alaska.edu/afgjp/PADM601\%20Fall\%202011/Using\%20Online $\% 20$ Tools\%20to\%20Engage\%20The\%20Public_0.pdf. 
Leighninger, Matt. 2014. "Want to Increase Trust in Government? Update Our Public Participation Laws.” Public Administration Review 74 (3): 305-306.

Local Government Act 1989 (Vic). Accessed October 72017. http://www.legislation.vic.gov.au/domino/Web_Notes/LDMS/LTObject_Store/ltobjst9. nsf/DDE300B846EED9C7CA257616000A3571/BDFF95C10DE3BD01CA257F0E008 2D5F2/\$FILE/89-11aa135\%20authorised.PDF.

Local Government Act 1993 (NSW). Accessed October 72017. http://www.legislation.nsw.gov.au/acts/1993-30.pdf.

Local Government Act 1993 (Tas). Accessed October 72017. http://www.austlii.edu.au/au/legis/tas/num_act/lga199395o1993228/.

Local Government Act 1995 (WA). Accessed October 72017. http://www.austlii.edu.au/au/legis/wa/num_act/lga199574o1995228/lga199574o199522 8.pdf.

Local Government Act 1999 (SA). Accessed October 72017. https://www.legislation.sa.gov.au/LZ/C/A/LOCAL\%20GOVERNMENT\%20ACT\%20 1999/CURRENT/1999.62.AUTH.PDF.

Local Government Act 2009 (Qld). Accessed October 72017. https://www.legislation.qld.gov.au/view/html/asmade/act-2009-017.

Local Government Act 2017 (NT). Accessed August 292018. https://legislation.nt.gov.au/Legislation/LOCAL-GOVERNMENT-ACT

Lowndes, Vivien, Lawrence Pratchett, and Gerry Stoker. 2001. "Trends in Public Participation: Part 1 - Local Government Perspectives." Public Administration 79 (1): 205-222.

Lukensmeyer, Carolyn J. 2013. Bringing Citizen Voices to the Table: A Guide for Public Managers. San Francisco: Joessey-Bass.

McComas, Katherine, Besley, C. John, and Laura W. Black. 2010. "The Rituals of Public Meetings." Public Administration Review 70: 122-130.

Michels, Ank, and Laurens De Graaf. 2017. "Examining Citizen Participation: Local Participatory Policymaking and Democracy Revisited." Local Government Studies, August. Routledge, 1-7.

Mill, John Stuart. 1861 (1972). Considerations on Representative Government. In Acton, H. B. (Ed.). John Stuart Mill. Utilitarianism, On Liberty, Considerations on Representative Government. London: Everyman, pp. 188-428.

Morris, R. 2012. Community Engagement in Rural-Remote and Indigenous Local Government. Australian Centre of Excellence for Local Government, University of Technology Sydney. 
Nabatchi, Tina, and Lisa Blomgren Amsler. 2014. "Direct Public Engagement in Local Government.” American Review of Public Administration 44 (4): 63S - 88S.

Nabatchi, Tina, Alessandro Sancino, and Mariafrancesca Sicilia. 2017. "Varieties of Participation in Public Services: The Who, When, and What of Coproduction." Public Administration Review 77 (5): 50-61.

Power, John, Roger Wettenhall, and John Halligan, eds. 1981. Local Government Systems of Australia, Advisory Council for Inter-Government Relations. Vol. Information Paper No. 7. Canberra: Australian Government Publishing Service.

Pratchett, Lawrence. 2004. "Local Autonomy, Local Democracy and the 'New Localism."” Political Studies 52 (2). Blackwell Publishing Ltd.: 358-375.

Reddel, Tim, and Geoff Woolcock. 2004. "From Consultation to Participatory Governance? A Critical Review of Citizen Engagement Strategies in Queensland." Australian Journal of Public Administration 63 (3): 75-87.

Rowe, Gene, and Lynn J. Frewer. 2005. "A Typology of Public Engagement Mechanisms." Science, Technology and Human Values 30 (2): 251-290.

Sandoval-Almazan, Rodrigo, and J. Ramon Gil-Garcia. 2012. "Are Government Internet Portals Evolving towards More Interaction, Participation, and Collaboration? Revisiting the Rhetoric of E-Government among Municipalities." Government Information Quarterly 29 (Supplement 1): S72-S81.

Stoker, Gerry. 2006. "Public Value Management: A New Narrative for Networked Governance?" American Review of Public Administration 36 (1): 41-57.

Tiebout, Charles M. 1956. 'A Pure theory of Local Expenditures'. Journal of Political Economy, pp. 416-424.

United Nations. 2005. "Brisbane Declaration on Community Engagement." First International Conference on Engaging Communities. http://www.ncdd.org/exchange/files/docs/brisbane_declaration.pdf.

Voorberg, W. H., V. J. J. M. Bekkers, and L. G. Tummers. 2015. “A Systematic Review of Co-Creation and Co-Production: Embarking on the Social Innovation Journey." Public Management Review 17 (9): 1333-1357.

Wang, Xiaohu. 2001. "Assessing Public Participation in U.S. Cities.” Public Performance \& Management Review 24 (4): 322-336.

Wang, Xiaohu, and Montgomery van Wart. 2007. "When Public Participation in Administration Leads to Trust: An Empirical Assessment of Managers' Perceptions." Public Administration Review 67 (2): 265-278.

Working Group on Legal Frameworks for Public Participation. 2013. "Making Public Participation Legal." Denver, Colorado. http://ncdd.org/rc/wpcontent/uploads/MakingP2Legal.pdf. 
